\title{
Vocal Nodules and Polyps: Clinical and Histological Diagnosis
}

\author{
Sushna Maharjan ${ }^{1 *}$, Ramesh Parajuli² and Puja Neopane ${ }^{3}$ \\ ${ }^{1}$ Department of Pathology, Chitwan Medical College Teaching Hospital, Nepal \\ ${ }^{2}$ Department of Department of Otorhinolaryngology, Chitwan Medical College Teaching Hospital, Nepal \\ ${ }^{3}$ Department of Oral Medicine and Pathology, School of Dentistry, Health Sciences University of Hokkaido, Japan
}

Submission: June 19, 2017; Published: July 07, 2017

*Corresponding author: Sushna Maharjan, Department of Pathology, Chitwan Medical College Teaching Hospital (CMC-TH), P.O. Box 42,

Bharatpur, Chitwan, Nepal, Email: sushnamaharjan74@gmail.com

\begin{abstract}
Vocal nodules and polyps are the most common benign laryngeal lesions. Recent studies have emphasized the importance of the clinicohistological correlation in laryngeal pathologies. The clinico-histological correlation of these lesions is not always easy, but an accurate diagnosis is of the utmost importance.
\end{abstract}

Keywords: Laryngeal; Nodule; Polyp; Vocal

\section{Introduction}

Vocal nodules and polyps are the most common benign laryngeal lesions which are diagnosed primarily by patient history, clinical complaints and through visual examination such as indirect laryngoscopy with rigid or flexible fiber optic scope and stroboscopy. The etiology of both is commonly related to vocal abuse and microscopically both are defined as identical lesions. The development of new noninvasive diagnostic methods and advances in the study of semiology, laryngeal physiology and histopathology are allowing a thorough assessment of laryngeal lesions in the vocal folds. Recent studies have emphasized the importance of the clinico-histological correlation in laryngeal pathologies.

\section{Discussion}

\section{Vocal polyps}

Vocal polyps can be sessile or pedunculated, unilateral or bilateral. They occur commonly at the free edge of the vocal fold characterized as edematous, hyaline or mixed [1]. Acute or chronic voice abuse results in micro-vascular trauma that leads to sub-cellular changes. These polyps typically affect adults whose work involves frequent voice stress [2], for example, teachers and they are also at higher risk of vocal fold cysts and nodules [3]. The typical histological features are found in the lamina propria, such as edematous changes, increased capillaries and inflammation are characteristic [2]. The same histological changes can often be seen in vocal fold nodules and Reinke's edema [4].

Besides the repetitive trauma, the addition causes that may contribute to polyp formation are airway infections, allergies, nicotine, gastro-esophageal reflux, aspirin and other blood thinning medications [2]. The size and location of the polyps is directly correlated to voice quality. These polyps are purely structural and surgical problem but the otolaryngologist should always check the specific requirements of the patient for his work and leisure time, and organize the relevant voice diagnostics. Recurrence is possible even with successful surgical dissection if the underlying pathogenesis is ignored. It is suggestive for postoperative voice therapy in some cases although voice therapy as the sole treatment modality is unlikely to cure vocal fold polyps despite anecdotal reports of its success [5].

\section{Vocal nodules}

Vocal nodules (e.g. singer's nodes) are the consequence of functional voice disorders, also caused by vocal abuse or misuse. Typically these nodules are bilaterally symmetrical in the middle third of the vocal fold and located superficially on the vibrating free edge of the fold. The anatomical diagnosis can be difficult because of the heterogeneity of lesions ranging from discrete, poorly circumscribed edematous lesions to hard, horny nodules [6]. Stroboscopic examination reveals the incomplete glottis 
closure (classically an hour-glass closure pattern) that can help making the diagnosis [7]. Patients often present with a poor vocal endurance and a quickly tiring voice.

An increased vocal load, for example, due to the patient's profession, is usually, responsible for the formation of nodules. Boys, young women and teachers are particularly affected [8]. The pathogenesis of vocal nodules is due to the disproportionately high mechanical shear on the free edge of the vocal fold which damages the superficial layer of the lamina propria and results in micro-vascular changes in the middle third of the fold. With time, it results in remodeling of the tissue with increasing hyalinization and epithelial hyperplasia, leading to typically circumscribed lesions in the vocal folds. On histological examination, thickening of the basement membrane and an edematous swelling of the lamina propria are characteristic [9].

It is often difficult to diagnose different lesions of the lamina propria histologically (eg. nodules, polyps and Reinke's edema) $[10,11]$. Therefore, the correct diagnosis cannot be made purely on histological examination, but requires a complete assessment including history, voice assessment and laryngoscopic/ stroboscopic findings [12]. It is also worth noting that the diagnoses of vocal polyps and nodules are not always concordant clinically and histologically but an accurate diagnosis is of the utmost importance and should try the best for correct diagnosis. The viable therapeutic measures for nodules are conservative voice hygiene and voice therapy. The patient's motivation, vocal requirements in social and professional life together with the correct diagnosis allows an appropriate conservative treatment plan to be formulated. The specifically tailored program, including targeted voice therapy, achieves better results than a generic program [13].

There is often a subjective and objective improvement of the voice that may not always match by improvements in the laryngoscopic/stroboscopic findings. Phonosurgery may be indicated if conservative measures fail to achieve the desired results $[14,15]$. Furthermore, it is noteworthy that surgery does not necessarily correct the underlying causal process at hand [12]. Hence voice therapy is the key to gain a long lasting improvement after surgery and reduces recurrence rate.

\section{Conclusion}

The diagnoses of vocal polyps and nodules are not always concordant clinically and histologically, but an accurate diagnosis is of the utmost importance.

\section{References}

1. Wallis L, Jackson-Menaldi C, Holland W, Giraldo A (2004) Vocal fold nodule vs. vocal fold polyp: answer fromsurgical pathologist and voice pathologist point of view. J Voice 18(1): 125-129.

2. Martins RH, Defaveri J, Domingues MA, de Albuquerque e Silva R (2011) Vocal polyps: clinical, morphological, and immunohistochemical aspects. J Voice 25(1): 98-106.

3. Thibeault SL, Merrill RM, Roy N, Gray SD, Smith EM (2004) Occupational risk factors associated with voice disorders among teachers. Ann Epidemiol. 14(10): 786-792.

4. Hantzakos A, Remacle M, Dikkers FG, Degols JC, Delos M, et al. (2009) Exudative lesions of Reinke's space: a terminology proposal. Eur Arch Otorhinolaryngol 266(6): 869-878.

5. Srirompotong S, Saeseow P, Vatanasapt P (2004) Small vocal cord polyps: completely resolved with conservative treatment. Southeast Asian J TropMed Public Health 35(1): 169-71.

6. Rubin AD, Gherson S, Sataloff RT (2004) Vocal fold nodules. Ear Nose Throat J 83(7): 450.

7. Sataloff RT, Spiegel JR, Hawkshaw MJ (1991) Strobovideolaryngoscopy: results and clinical value. Ann Otol Rhinol Laryngol 100(9 Pt 1): 725727.

8. Smolander S, Huttunen K (2006) Voice problems experienced by Finnish comprehensive school teachers and realization of occupational health care. Logoped Phoniatr Vocol 31(4): 166-171.

9. Martins RH, Defaveri J, Custódio Domingues MA, de Albuquerque e Silva R, Fabro A (2010) Vocal fold nodules: morphological and immunohistochemical investigations. J Voice 24(5): 531-539.

10. Marcotullio D, Magliulo G, Pietrunti S, Suriano M (2002) Exudative laryngeal diseases of Reinke's space: a clinicohistopathological framing. J Otolaryngol 31(6): 376-380.

11. Dikkers FG, Nikkels PG (1999) Lamina propria of the mucosa of benign lesions of the vocal folds. Laryngoscope 109(10):1684-1689.

12. Pedersen M, McGlashan J (2012) Surgical versus non-surgical interventions for vocal cord nodules. Cochrane Database Syst Rev 6: CD001934.

13. Behrman A, Rutledge J, Hembree A, Sheridan S (2008) Vocal hygiene education, voice production therapy, and the role of patient adherence: a treatment effectiveness study in women with phonotrauma. J Speech Lang Hear Res. 51(2): 350-366.

14. Leonard R (2009) Voice therapy and vocal nodules in adults. Curr Opin Otolaryngol Head Neck Surg 17(6): 453-457.

15. Holmberg EB, Hillman RE, Hammarberg B, Södersten M, Doyle P (2001) Efficacy of a behaviorally based voice therapy protocol for vocal nodules. J Voice 15(3): 395-412. 

$\begin{array}{ll}\text { CC } 19 & \text { This work is licensed under Creative } \\ \text { Commons Attribution 4.0 License } \\ \text { DOI: } 10.19080 / \text { GJO.2017.08.555744 }\end{array}$
Your next submission with Juniper Publishers will reach you the below assets

- Quality Editorial service

- Swift Peer Review

- Reprints availability

- E-prints Service

- Manuscript Podcast for convenient understanding

- Global attainment for your research

- Manuscript accessibility in different formats

( Pdf, E-pub, Full Text, Audio)

- Unceasing customer service

Track the below URL for one-step submission https://juniperpublishers.com/online-submission.php 